\title{
Synthesis of 5-substituted \\ 7,9-dihydro-8H-[1,3]dioxolo[4,5-h][2,3]benzodiazepin-8-ones as anticonvulsant agents
}

\author{
Maria Zappalà, ${ }^{\mathrm{a}}$ Nicola Micale, ${ }^{\mathrm{a}}$ Silvana Grasso,, ${ }^{\mathrm{a},}$ Frank S. Menniti, \\ Giovambattista De Sarro, ${ }^{c}$ and Carlo De Micheli ${ }^{\mathrm{d}}$ \\ ${ }^{a}$ Dipartimento Farmaco-Chimico, Università di Messina, viale Annunziata, 98168 Messina, \\ Italy, \\ ${ }^{b}$ Pfizer Global Research and Development, Eastern Point Road, Groton, CT 06340, USA, \\ ${ }^{c}$ Dipartimento di Medicina Sperimentale e Clinica, Università di Catanzaro, Via T. Campanella, \\ 88100 Catanzaro, Italy, \\ ${ }^{d}$ Istituto di Chimica Farmaceutica, Università di Milano, viale Abruzzi, 42, 20131 Milano, Italy \\ E-mail:grasso@pharma.unime.it
}

\section{Dedicated to Professor Vincenzo Tortorella on the occasion of his "Fuori Ruolo" status (received 19 Dec 03; accepted 05 Mar 04; published on the web 10 Mar 04)}

\begin{abstract}
5-(4-Aminobenzyl)-7,9-dihydro- $8 H$-[1,3]dioxolo[4,5-h][2,3]benzodiazepin-8-one (3) and 7,9dihydro-5-[2-(pyridin-2-yl)-vinyl]- $8 H$-[1,3]dioxolo[4,5-h][2,3]benzodiazepin-8-one (4) were synthesized and screened as anticonvulsant agents in DBA/2 mice against sound-induced seizures. The new compounds are provided with anticonvulsant properties even if $\mathrm{ED}_{50}$ values are lower than those of prototype 5-(4-aminophenyl)-7,9-dihydro-8H-[1,3]dioxolo[4,5h][2,3] benzodiazepin-8-one (2) and of GYKI 52466 (1), a well-known noncompetitive AMPA receptor antagonist. Binding assays and functional tests were performed to evaluate the affinity for AMPA and kainate receptors.
\end{abstract}

Keywords: 7,9-Dihydro- $8 H$-[1,3]dioxolo[4,5-h][2,3]benzodiazepin-8-ones, anticonvulsant activity

\section{Introduction}

Ionotropic glutamate receptors (iGluRs) are the major excitatory neurotransmitter receptor proteins in the mammalian brain. ${ }^{1,2}$ As a class of membrane proteins, iGluRs are composed of subunits that span the membrane to form a small pore or channel, which is gated by glutamate, a neurotransmitter. When glutamate is released from a presynaptic neuron and binds to a postsynaptic glutamate receptor, the receptor rapidly changes its conformation and transiently forms an open ion channel, thus resulting in a change of the postsynaptic membrane potential. A postsynaptic potential of sufficient strength triggers an action potential, which will in turn 
propagate the initial nerve impulse. The major function of iGluRs is to mediate fast synaptic neurotransmission underlying the basic activities of the brain, such as memory and learning. Overactivation of the receptors, on the other hand, has been implicated in a number of neurological diseases such as post-ischemia cell death, epilepsy, Huntington's chorea, and amyotrophic lateral sclerosis. ${ }^{1}$ To date, three major subtypes of iGluRs have been identified: NMDA ( $N$-methyl-D-aspartate), kainate, and AMPA (2-amino-3-(3-hydroxy-5-methylisoxazol4-yl)propionic acid) receptors, and classified on the basis of amino acid sequences, pharmacological profiles, and biological functions. ${ }^{1,2}$

5-(4-Aminophenyl)-8-methyl-9H-[1,3]dioxolo[4,5-h][2,3]benzodiazepine (1, GYKI 52466, Figure 1), a 2,3-benzodiazepine derivative, is the prototype of selective noncompetitive AMPA receptor antagonists acting via an allosteric site on the receptor complex. ${ }^{3}$ It possesses remarkable anticonvulsant properties ${ }^{4,5}$ and behaves as a neuroprotective agent in focal and global ischemia. ${ }^{6}$

Based on the anticonvulsant properties of the previously described ${ }^{7,8} 5$-(4-aminophenyl)-7,9dihydro- $8 \mathrm{H}$-[1,3]dioxolo[4,5-h][2,3]benzodiazepin-8-one (2), where the iminohydrazone portion of 1 was replaced by the iminohydrazide moiety, we designed 5-(4-aminobenzyl)-7,9-dihydro$8 \mathrm{H}$-[1,3]dioxolo[4,5-h][2,3]benzodiazepin-8-one (3) and 7,9-dihydro-5-[2-(pyridin-2-yl)-vinyl]$8 H$-[1,3]dioxolo[4,5-h][2,3]benzodiazepin-8-one (4) (Figure 1) in order to explore the influence of the substituent appended at position 1 on the anticonvulsant activity. In particular we inserted in such a position the 4-aminobenzyl group, in order to interrupt the electronic connection between the aryl group and the unsaturated heterocyclic ring, and the 2-(pyridin-2-yl)-vinyl moiety which seems to play a role of utmost importance in a strictly-related class of new noncompetitive AMPA receptor antagonists. ${ }^{9}$

Herein, we report the synthesis and the anticonvulsant properties of derivatives $\mathbf{3}$ and $\mathbf{4}$ along with the results of binding assays and functional tests performed at both AMPA and kainate receptors.

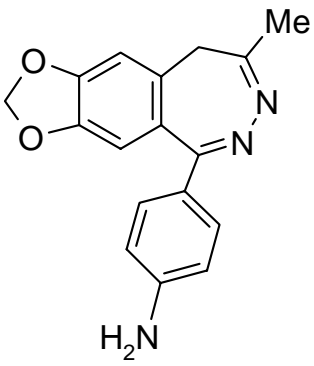

1, GYKI 52466

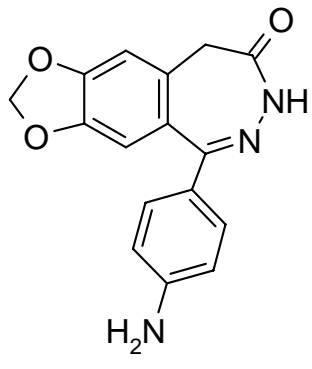

2

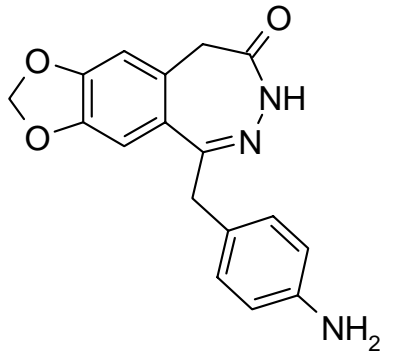

3

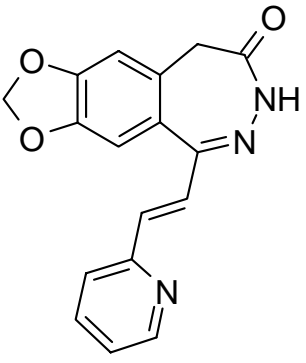

4

\section{Figure 1}




\section{Results and Discussion}

\section{Chemistry}

The synthesis of novel compounds $\mathbf{3}$ and $\mathbf{4}$ was accomplished following the reaction sequence reported in Schemes 1-2.

Ketoester 6 was easily prepared via acylation of methyl 1,3-benzodioxol-5-ylacetate 5 with 4-nitrophenylacetic acid in the presence of excess phosphorous pentoxide. The subsequent treatment with hydrazine gave 7,9-dihydro-5-(4-nitrobenzyl)-8H-[1,3]dioxolo[4,5h] [2,3] benzodiazepin-8-one (7) in good yields. Reduction of the nitro group of 7, carried out with Raney-Ni/ammonium formate, afforded target derivative 3.

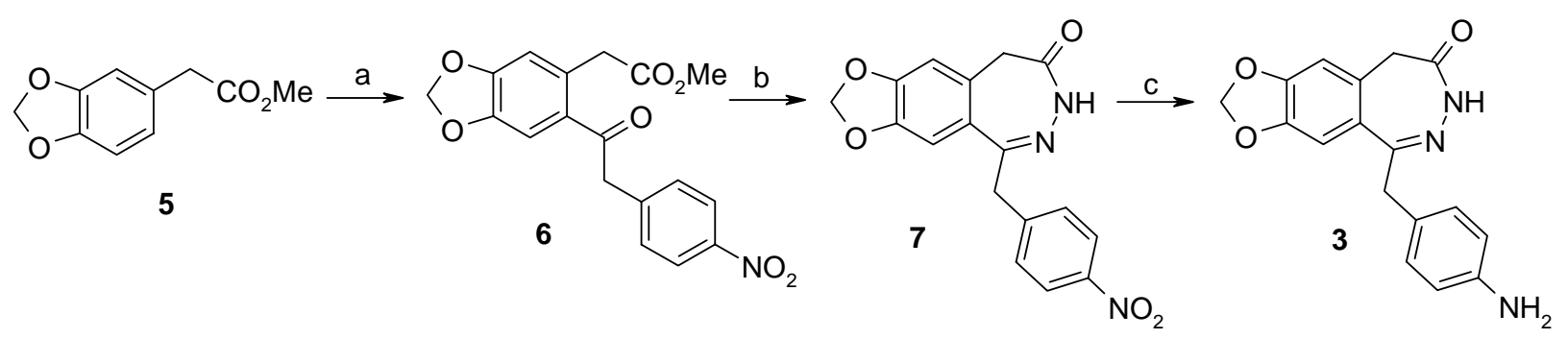

Scheme 1. (a) 4-nitrophenylacetic acid, $\mathrm{P}_{2} \mathrm{O}_{5},\left(\mathrm{CH}_{2} \mathrm{Cl}\right)_{2}$, rt, 16h; (b) $\mathrm{NH}_{2} \mathrm{NH}_{2}, \mathrm{MeOH}$, reflux, 48h; (c) Raney-Ni, ammonium formate, EtOH, reflux, $2 \mathrm{~h}$.

7,9-Dihydro-5-[2-(pyridin-2-yl)-vinyl]-8H-[1,3]dioxolo[4,5-h][2,3]benzodiazepin-8-one (4) was easily synthesized by a Friedel-Craft acylation of 5 with acetic anhydride in the presence of tin(IV) chloride as the catalyst followed by a treatment with hydrazine to afford intermediate 9. Condensation of $\mathbf{9}$ with pyridine-2-carboxaldehyde to produce vinyl derivative $\mathbf{4}$ was conveniently accomplished with acetic anhydride and anhydrous zinc chloride in refluxing dioxane.

Physical and spectral data $\left({ }^{1} \mathrm{H}\right.$ NMR) of the synthesized compounds are in agreement with the proposed structures. In compound 4 , the stereochemistry around the $\mathrm{C}=\mathrm{C}$ bond was assigned as $E$, on the basis of the coupling constant value $(J=16.2 \mathrm{~Hz})$ between the two protons of the vinyl moiety.

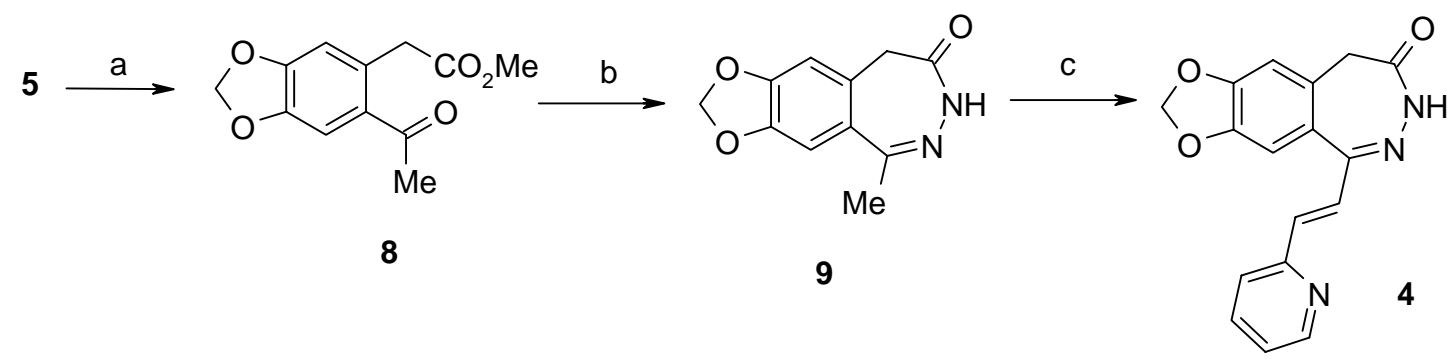

Scheme 2. (a) acetic anhydride, $\mathrm{SnCl}_{4}, \mathrm{CH}_{2} \mathrm{Cl}_{2}, \mathrm{rt}, 16 \mathrm{~h}$; (b) $\mathrm{NH}_{2} \mathrm{NH}_{2}, \mathrm{MeOH}$, reflux, 48h; (c) pyridine-2-carboxaldehyde, acetic anhydride, $\mathrm{ZnCl}_{2}$, dioxane, reflux, $16 \mathrm{~h}$. 


\section{Pharmacology}

The anticonvulsant activity of derivatives $\mathbf{3}$ and $\mathbf{4}$ against audiogenic seizures was evaluated 30 min after intraperitoneal administration to DBA/2 mice, a strain genetically susceptible to soundinduced seizures. This test has been considered an excellent animal model for generalized epilepsy and for screening new anticonvulsant drugs. ${ }^{10}$ The results are compared with those previously reported for derivative 2 and reference compound $\mathbf{1}$ (Table 1). ${ }^{7,8}$

As shown in Table 1, compound 4 possesses anticonvulsant properties lower than those of prototype $\mathbf{2}$ as well of lead compound $\mathbf{1}$ whereas derivative 3, even if unable to prevent the clonic phase of the audiogenic seizures, significantly reduces the tonic phase of the seizures; its $\mathrm{ED}_{50}$ value is comparable to that of GYKI 52466.

Table 1. Anticonvulsant activity of compounds 1-4 against audiogenic seizures in DBA/2 mice and $\mathrm{TD}_{50}$ values on locomotion assessed by rotarod test ${ }^{\mathrm{a}}$

\begin{tabular}{|c|c|c|c|}
\hline \multirow[t]{2}{*}{ Compds } & \multicolumn{2}{|c|}{$\mathrm{ED}_{50}, \mu \mathrm{mol} / \mathrm{kg}$} & \multirow{2}{*}{$\begin{array}{l}\mathrm{TD}_{50}, \mu \mathrm{mol} / \mathrm{kg} \\
\text { locomotor deficit }\end{array}$} \\
\hline & Clonic phase & Tonic phase & \\
\hline 1 & $35.8(24.4-52.4)$ & $25.3(16.0-40.0)$ & $76.1(47.5-122)$ \\
\hline 2 & $18.0(10.0-32.5)$ & $12.7(6.13-26.2)$ & $101(52.0-194)$ \\
\hline 3 & $>80$ & $24.1(13.6-42.7)$ & $>150$ \\
\hline 4 & $81.2(52.2-126)$ & $65.5(46.7-91.8)$ & $>150$ \\
\hline
\end{tabular}

${ }^{a}$ All compounds were given ip (at doses spanning the range 3.3-200 $\mu \mathrm{mol} / \mathrm{kg}$ ) $30 \mathrm{~min}$ before auditory stimulation. All data were calculated according to the method of Litchfield and Wilcoxon; ${ }^{17} 95 \%$ confidence limits are given in brackets. At least 32 animals were used to calculate each $\mathrm{ED}_{50}$ and $\mathrm{TD}_{50}$ value.

For this reason, compound 3 was also examined for its ability to displace $\left[{ }^{3} \mathrm{H}\right] \mathrm{CP}-526,427$ from the corresponding binding site of the AMPA receptor complex (Table 2). The inhibition of $\left[{ }^{3} \mathrm{H}\right] \mathrm{CP}-526,427$ specific binding $(3 \mathrm{nM})$ to rat forebrain membranes was evaluated as previously described. ${ }^{11,12}$ In this assay, the quinazolinone CP-465,022 was used as a positive control; its $\mathrm{IC}_{50}$ values spanned the range $20-40 \mathrm{nM}$. Compound 3 turned out to be totally inactive ( $\mathrm{IC}_{50}$ $>100 \mu \mathrm{M})$, differently to that observed ${ }^{13}$ for compound 2 which showed $\mathrm{IC}_{50}=32 \mu \mathrm{M}$, a value similar to that reported for GYKI $52466\left(\mathrm{IC}_{50}=12.6 \mu \mathrm{M}\right)$.

Furthermore, compound 3 was tested for its ability to inhibit the kainate-induced increase of the $\left[\mathrm{Ca}^{2+}\right] \mathrm{i}$ in a primary culture of rat cerebellar granule cells (CGC) which express AMPA receptors (Table 2); GYKI 52466 was used as the control. The same test was carried out in rat HEK293 cells expressing GluR5, a kainate receptor subtype, stimulated by domoic acid; SYM 2081 was used as the control.

The results of the CGC test confirmed the data of the binding experiments, namely compound 3 at $100 \mu \mathrm{M}$ produced solely a 20\% inhibition of calcium influx, whereas derivative 2 
turned out to be slightly more potent than 1 ( $\mathrm{IC}_{50} 13 \mu \mathrm{M}$ for 2 vs $22 \mu \mathrm{M}$ for $\mathbf{1}$ ) (Table 2). In the iGluR5/HEK293 cells test, compound 3, assayed up to $10 \mu \mathrm{M}$, showed neither agonistic nor antagonistic activity.

Table 2. Pharmacological data of compounds 2-3. and of reference compounds GYKI 52466 and SYM 2081

\begin{tabular}{cccc}
\hline Compd & $\begin{array}{c}\left.{ }^{3} \mathrm{H}\right] \mathrm{CP}-526,427^{\mathrm{a}} \\
\mathrm{IC}_{50}(\mu \mathrm{M})\end{array}$ & $\begin{array}{c}\mathrm{KA}-\left[\mathrm{Ca}^{2+}\right] \mathrm{i} \\
\mathrm{IC}_{50}(\mu \mathrm{M}) \text { or } \mathrm{I} \%\end{array}$ & $\begin{array}{c}\text { Domoic acid- }\left[\mathrm{Ca}^{2+}\right] \mathrm{i} \\
\mathrm{IC}_{50}(\mu \mathrm{M})\end{array}$ \\
\hline $\mathbf{2}$ & 32 & 13 & - \\
$\mathbf{3}$ & $>100$ & $20 \%$ & $>10$ \\
GYKI 52466 & 12.6 & 22 & - \\
SYM 2081 & - & - & 0.047 \\
\hline
\end{tabular}

${ }^{\mathrm{a}}$ Applied (3 $\left.\mathrm{nM}\right)$ to rat forebrain membranes.

To sum up, the results reported in this study suggest that the 4-aminophenyl group directly linked to the unsaturated heterocycle is a fragmental requirement necessary to confer anticonvulsant activity to compounds structurally related to derivative 2 . The insertion of a methylene between the aryl group and the unsaturated heterocyclic ring to interrupt their electronic connection or an extension of their conjugation through the insertion of a vinyl moiety, in both cases, bring about a drastic reduction in the anticonvulsant activity.

\section{Experimental Section}

General Procedures. Melting points were determined on a Kofler hot stage apparatus and are uncorrected. Elemental analyses were carried out on a C. Erba Model 1106 Elemental Analyzer for $\mathrm{C}, \mathrm{H}$ and $\mathrm{N}$ ) and the results are within $\pm 0.4 \%$ of the theoretical values. Merck silica gel 60 $\mathrm{F}_{254}$ plates were used as analytical TLC; column chromatography was performed on Merck silica gel 60 (70-230 mesh). IR spectra were obtained on a Perkin Elmer Spectrum BX FT-IR as nujol mulls. ${ }^{1} \mathrm{H}-\mathrm{NMR}$ spectra were recorded in $\mathrm{CDCl}_{3}$ by means of a Varian Gemini 300 spectrometer. Chemical shifts are expressed in $\delta(\mathrm{ppm})$ relative to TMS as internal standard and coupling constants $(J)$ in $\mathrm{Hz}$.

Methyl 6-[(4-nitrophenyl)acetyl]-1,3-benzodioxol-5-ylacetate (6). 4-Nitropheylacetic acid (606 $\mathrm{mg}, 3.3 \mathrm{mmol})$ and phosphorous pentoxide $(2.0 \mathrm{~g})$ were added to a stirred 1,2dichloroethane solution (50 mL) of methyl 1,3-benzodioxol-5-ylacetate $5^{14}$ (500 mg, $\left.2.6 \mathrm{mmol}\right)$. The mixture was further stirred at room temperature overnight, then water $(30 \mathrm{~mL})$ was cautiously added and the mixture extracted with chloroform $(2 \times 30 \mathrm{~mL})$. The organic layer was separated and sequentially treated with $10 \% \mathrm{NaOH}(30 \mathrm{~mL})$, brine $(30 \mathrm{~mL})$ and water $(2 \mathrm{x}$ $30 \mathrm{~mL})$. The organic phase was dried $\left(\mathrm{Na}_{2} \mathrm{SO}_{4}\right)$ and the solvent removed under reduced pressure 
to yield crude 6 which was purified by crystallization with diethyl ether/light petroleum. Mp $128-131{ }^{\circ} \mathrm{C}$ (orange powder) $(745 \mathrm{mg}, 81 \%) \mathrm{R}_{\mathrm{f}}=0,36\left(\mathrm{Et}_{2} \mathrm{O} /\right.$ light petroleum $\left.60 / 40\right)$; IR (nujol): 1727, $1665 \mathrm{~cm}^{-1} .{ }^{1} \mathrm{H} \mathrm{NMR}\left(\mathrm{CDCl}_{3}\right): 3.66\left(\mathrm{~s}, 3 \mathrm{H}, \mathrm{CH}_{3}\right), 3.85\left(\mathrm{~s}, 2 \mathrm{H}, \mathrm{CH}_{2}-1\right), 4.30(\mathrm{~s}, 2 \mathrm{H}$, $\left.\mathrm{COCH}_{2} \mathrm{Ar}\right), 6.07$ (s, 2H, OCH$\left.{ }_{2} \mathrm{O}\right), 6.74$ (s, 1H, H-6), 7.33 (s, 1H, H-3), 7.40 (d, 2H, J = 8.8, H2',6'), 8.20 (d, 2H, $J=8.8, \mathrm{H}-3$ ',5'). Anal. calcd. for $\mathrm{C}_{18} \mathrm{H}_{15} \mathrm{NO}_{7}$ : C, 60.51; H, 4.23; N, 3.92 . Found: C, 60.36; H, 4.17; N, 4.04 .

7,9-Dihydro-5-(4-nitrobenzyl)-8H-[1,3] dioxolo[4,5-h][2,3]benzodiazepin-8-one (7). Hydrazine hydrate $(0.28 \mathrm{~mL}, 5.82 \mathrm{mmol})$ was added to a solution of compound $6(650 \mathrm{mg}, 1.82 \mathrm{mmol})$ in methanol $(40 \mathrm{~mL})$; the mixture was acidified to $\mathrm{pH} 3$ by addition of $3 \mathrm{~N} \mathrm{HCl}$ then heated at reflux for $48 \mathrm{~h}$. The solvents were removed under reduced pressure and the residue was dissolved with EtOAc and poured into water. The organic layer, dried over $\mathrm{Na}_{2} \mathrm{SO}_{4}$, was evaporated under reduced pressure and the residue was purified by a silica gel column chromatography (eluant: EtOAc/cyclohexane, 60:40) to afford pure 7. Mp 229-232 ${ }^{\circ} \mathrm{C}$ (beige powder) $(424 \mathrm{mg}, 60 \%) R_{\mathrm{f}}=$ 0,39 (EtOAc/cyclohexane 60/40); IR (nujol): 3179, $1684 \mathrm{~cm}^{-1} .{ }^{1} \mathrm{H}$ NMR $\left(\mathrm{CDCl}_{3}\right): 3.22$ (s, 2H, $\left.\mathrm{CH}_{2}-5\right), 4.19$ (s, 2H, $\left.\mathrm{CH}_{2}-1\right), 6.04$ (s, 2H, $\mathrm{OCH}_{2} \mathrm{O}$ ), 6.70 (s, 1H, H-9), 6.94 (s, 1H, H-6), 7.38 (d, $\left.2 \mathrm{H}, J=8.8, \mathrm{H}-2^{\prime}, 6^{\prime}\right), 8.13$ (d, 2H, $\left.J=8.8, \mathrm{H}-3^{\prime}, 5^{\prime}\right), 8.37$ (bs, 1H, NH). Anal. calcd. for: $\mathrm{C}_{17} \mathrm{H}_{13} \mathrm{~N}_{3} \mathrm{O}_{5}$ : C, 60.18; H, 3.86; N, 12.38. Found: C, 60.32; H, 3.67; N, 12.14.

5-(4-Aminobenzyl)-7,9-dihydro-8H-[1,3]dioxolo[4,5-h][2,3]benzodiazepin-8-one (3). A suspension of 7 (392 mg, $1.15 \mathrm{mmol})$ and Raney-Ni $(60 \mathrm{mg})$ in EtOH $(40 \mathrm{~mL})$ was stirred with ammonium formate $(362 \mathrm{mg}, 5.75 \mathrm{mmol})$. The mixture was refluxed for $2 \mathrm{~h}$ and then filtered on celite. The organic layer was evaporated under reduced pressure and the residue, dissolved in $\mathrm{CHCl}_{3}$, was washed with saturated $\mathrm{NaCl}$ to remove ammonium formate. The organic layer, dried over $\mathrm{Na}_{2} \mathrm{SO}_{4}$, was evaporated under reduced pressure and the residue was purified by a silica gel column chromatography eluting with EtOAc. Mp 104-107 ${ }^{\circ} \mathrm{C}$ (pale beige powder) (317 mg, 82\%) $R_{\mathrm{f}}=0,42$ (EtOAc); IR (nujol): 3350 , 3220, $1667 \mathrm{~cm}^{-1}$. ${ }^{1} \mathrm{H}$ NMR $\left(\mathrm{CDCl}_{3}\right): 3.20$ (s, 2H, $\left.\mathrm{CH}_{2}-5\right), 3.61$ (bs, 2H, NH $\mathrm{NH}_{2}, 3.96$ (s, 2H, $\left.\mathrm{CH}_{2}-1\right), 6.00$ (s, 2H, $\mathrm{OCH}_{2} \mathrm{O}$ ), 6.57 (d, 2H, J = 8.5, H-3',5'), 6.67 (s, 1H, H-9), 6.96 (d, 2H, J = 8.5, H-2',6'), 6.97 (s, $1 \mathrm{H}, \mathrm{H}-6), 8.35$ (bs, $1 \mathrm{H}, \mathrm{NH})$. Anal. calcd. for $\mathrm{C}_{17} \mathrm{H}_{15} \mathrm{~N}_{3} \mathrm{O}_{3}$ : C, 66.01; H, 4.89; N, 13.58. Found: C, $66.23 ; \mathrm{H}, 4.76 ; \mathrm{N}, 13.33$.

Methyl 6-acetylbenzo[1,3]dioxol-5-ylacetate (8). Tin(IV) chloride (0.1 M $8 \mathrm{~mL}, 8 \mathrm{mmol})$ and acetic anhydride $(0,63 \mathrm{~mL}, 6.70 \mathrm{mmol})$ in $\mathrm{CH}_{2} \mathrm{Cl}_{2}(20 \mathrm{~mL})$ were added to a cooled $\left(0-5^{\circ} \mathrm{C}\right)$ and stirred solution of 3,4-methylenedioxyphenyl acetic acid methyl ester 5 ( $1 \mathrm{~g}, 5.15 \mathrm{mmol})$ in 20 $\mathrm{ml}$ of the same solvent. The ice-bath was removed and the mixture was stirred at $20^{\circ} \mathrm{C}$ overnight, then poured into water and the product was isolated in ether and dried over $\mathrm{Na}_{2} \mathrm{SO}_{4}$. The solvent was removed under reduced pressure and the residue purified by treatment with diethyl ether. $\mathrm{Mp}=111-114{ }^{\circ} \mathrm{C}$ (beige powder) $(1.14 \mathrm{~g}, 94 \%) R_{\mathrm{f}}=0.52\left(\mathrm{Et}_{2} \mathrm{O} /\right.$ light petroleum 60/40); IR (nujol): 1719, $1659 \mathrm{~cm}^{-1} .{ }^{1} \mathrm{H}$ NMR $\left(\mathrm{CDCl}_{3}\right): 2.53\left(\mathrm{~s}, 3 \mathrm{H}, \mathrm{COCH}_{3}\right), 3.71\left(\mathrm{~s}, 3 \mathrm{H}, \mathrm{COOCH}_{3}\right), 3.85$ (s, 2H, $\left.\mathrm{CH}_{2}-1\right), 6.05$ (s, 2H, $\left.\mathrm{OCH}_{2} \mathrm{O}\right), 6.72$ (s, 1H, H-6), 7.31 (s 1H, H-3), Anal. calcd. for $\mathrm{C}_{12} \mathrm{H}_{12} \mathrm{O}_{5}$ : C, 61.02; H, 5.12. Found: C, 61.22; H, 5.01.

7,9-Dihydro-5-methyl-8H-[1,3]dioxolo[4,5-h][2,3]benzodiazepin-8-one (9). Compound 9 was synthesized with a procedure similar to that reported for derivative $\mathbf{7}$ starting from compound 8 
(1.14 $\mathrm{g}, 4.83 \mathrm{mmol})$, and purified by a silica gel column chromatography eluting with EtOAc/MeOH (90/10). Mp 251-253 ${ }^{\circ} \mathrm{C}$ (white powder) $(748 \mathrm{mg}, 72 \%) R_{\mathrm{f}}=0.79(\mathrm{EtOAc} / \mathrm{MeOH}$ 90/10); IR (nujol): 3185, $1678 \mathrm{~cm}^{-1} .{ }^{1} \mathrm{H} \mathrm{NMR}\left(\mathrm{CDCl}_{3}\right): 2.44$ (s, 3H, $\left.\mathrm{CH}_{3}\right), 3.34$ (s, 2H, $\left.\mathrm{CH}_{2}-5\right)$, $6.03\left(\mathrm{~s}, 2 \mathrm{H}, \mathrm{OCH}_{2} \mathrm{O}\right), 6.74(\mathrm{~s}, 1 \mathrm{H}, \mathrm{H}-9), 6.92$ (s, 1H, H-6), 8.20 (bs, 1H, NH). Anal. calcd. for $\mathrm{C}_{11} \mathrm{H}_{10} \mathrm{~N}_{2} \mathrm{O}_{3}$ : C, 60.55; H, 4.62; N, 12.84: Found: C, 60,37; H, 4.86; N, 12.62.

\section{E-7,9-Dihydro-5-[2-(pyridin-2-yl)-vinyl]-8H-[1,3]dioxolo[4,5-h][2,3]benzodiazepin-8-one}

(4). An anhydrous dioxane solution $(40 \mathrm{ml})$ of $9(748 \mathrm{mg}, 3.43 \mathrm{mmol})$ was treated with 2pyridinecarboxaldehyde $(0.33 \mathrm{ml}, 3.43 \mathrm{mmol})$, acetic anhydride $(2 \mathrm{~mL})$ and an excess of anhydrous $\mathrm{ZnCl}_{2}$. The reaction mixture was refluxed overnight, then poured into water and extracted with chloroform $(2 \times 50 \mathrm{~mL})$. The organic layer, dried over $\mathrm{Na}_{2} \mathrm{SO}_{4}$, was evaporated under reduced pressure and the residue was purified by a silica gel column chromatography eluting with $\mathrm{CCl}_{4} / \mathrm{i}-\mathrm{PrOH}(95 / 5)$. Mp $240-243^{\circ} \mathrm{C}$ (white needles) $(643 \mathrm{mg}, 61 \%) R_{\mathrm{f}}=0.24$ ( $\mathrm{CCl}_{4} / \mathrm{i}$-PrOH 95/5); IR (nujol): 3188, $1676 \mathrm{~cm}^{-1} .{ }^{1} \mathrm{H}$ NMR $\left(\mathrm{CDCl}_{3}\right): 3.39$ (s, 2H, $\left.\mathrm{CH}_{2}-5\right), 6.06$ (s, $\left.2 \mathrm{H}, \mathrm{OCH}_{2} \mathrm{O}\right), 6.82(\mathrm{~s}, 1 \mathrm{H}, \mathrm{H}-9), 7.03(\mathrm{~s}, 1 \mathrm{H}, \mathrm{H}-6), 7.04\left(\mathrm{~d}, 1 \mathrm{H}, J_{\text {trans }}=16.2, \mathrm{CH}_{\text {vinyl }}\right)$ 7.20-8.67 $(\mathrm{m}, 4 \mathrm{H}, \mathrm{Py}-\mathrm{H}), 7.59\left(\mathrm{~d}, 1 \mathrm{H}, J_{\text {trans }}=16.2, \mathrm{CH}_{\text {vinyl }}\right), 8.57$ (bs, 1H, $\left.\mathrm{NH}\right)$. Anal. calcd. for $\mathrm{C}_{17} \mathrm{H}_{13} \mathrm{~N}_{3} \mathrm{O}_{3}$ : C, 66.44; H, 4.26; N, 13.67. Found: C, 66.31; H, 4,37; N, 13.78.

Audiogenic seizures test in DBA/2 mice. ${ }^{15} \mathrm{DBA} / 2$ mice (8-12 g, 22-25 days old) were purchased from Charles River (Calco, Como, Italy). Groups of 10 mice of either sex were exposed to auditory stimulation 30 min following administration of vehicle or each dose of drugs studied. The compounds were given ip $(0.1 \mathrm{~mL} / 10 \mathrm{~g}$ of body weight of the mouse) as a freshlyprepared solution in $50 \%$ DMSO and $50 \%$ sterile saline $(0.9 \% \mathrm{NaCl})$. Individual mice were placed under a hemispheric perspex dome (diameter $58 \mathrm{~cm}$ ) and $60 \mathrm{~s}$ were allowed for habituation and assessment of locomotor activity. Auditory stimulation (12-16 kHz, $109 \mathrm{~dB})$ was applied for 60 secs or until tonic extension occurred and induced a sequential seizure response in control DBA/2 mice, consisting of an early wild running phase, followed by generalized myoclonus and tonic flexion and extension, sometimes followed by respiratory arrest. The control and drug-treated mice were scored for latency to and incidence of the different phases of the seizures. ${ }^{16}$

Statistical analysis. The $\mathrm{ED}_{50}$ values of each phase of the audiogenic seizure were determined for each dose of compound administered, and dose-response curves were fitted using a computer program by the method of Litchfield and Wilcoxon. ${ }^{17}$ The median toxic dose $\left(\mathrm{TD}_{50}\right)$ values were estimated using the method of Litchfield and Wilcoxon. ${ }^{17}$

\section{Acknowledgments}

This work was financially supported by the Ministero dell'Istruzione, dell'Università e della Ricerca (MIUR - COFIN2003) - Rome, Italy. 


\section{References}

1. Dingledine, R.; Borges, K.; Bowie, D.; Traynelis, S. F. Pharmacol. Rev. 1999, 51, 7.

2. Hollmann, M.; Heinemann, S. Annu. Rev. Neurosci. 1994, 17, 31.

3. Sólyom, S.; Tarnawa, I. Curr. Pharm. Design 2002, 8, 913 and references cited therein.

4. Donevan, S. D.; Yamaguchi, S.; Rogawski, M. A. J. Pharmacol. Exp. Ther. 1994, 271, 25.

5. Chapman, A. G.; Smith, S. E.; Meldrum, B. S. Epilepsy Res. 1991, 9, 92.

6. Smith, S. E.; Meldrum, B. S. Stroke 1992, 23, 861.

7. De Sarro, A.; De Sarro, G.; Gitto, R.; Grasso, S.; Micale, N.; Quartarone, S.; Zappalà M. Bioorg. Med. Chem. Lett. 1998, 8, 971.

8. Micale, N.; Zappalà, M.; Grasso, S. Il Farmaco 2003, 58, 351.

9. Welch, W. M.; Ewing, F. E.; Huang, J.; Menniti, F. S.; Pagnozzi, M. J.; Kelly, K.; Seymour, P. A.; Guanowsky, V.; Guhan, S.; Guinn, M. R.; Critchett, D.; Lazzaro, J.; Ganong, A. H.; DeVries, K. M.; Staigers, T. L.; Chenard, B. L. Bioorg. Med. Chem. Lett. 2001, 11, 177.

10. (a) Chapman, A. G.; Croucher, M. J.; Meldrum, B. S. Arzneim. Forsch. 1984, 34, 1261. (b) Engstrom, F. L.; Woodbury, D. M. Epilepsia 1988, 29, 389.

11. Menniti, F. S.; Chenard, M. B.; Collins, M. F.; Ducat, M. F.; Elliot, M. L.; Ewing, F. E.; Huang, J. I.; Kelly, K. A.; Lazzaro, J. T.; Pagnozzi, M. J.; Weeks, J. L.; Welch, W. M.; White, W. F. Mol. Pharmacol. 2000, 58, 1310.

12. Parks, T. N.; Artman, L. D.; Alasti, N.; Nemeth, E. F. Brain Res. 1991, 552, 13.

13. Grasso, S.; Micale, N.; Zappala, M.; Galli, A.; Costagli, C.; Menniti, F. S.; De Micheli, C. Bioorg. Med. Chem. Lett. 2003, 13, 443.

14. Cabedo, N.; Andreu, I.; Ramirez de Arellano, M. C.; Chagraoui, A.; Serrano, A.; Bermejo, A.; Protais, P.; Cortes, D. J. Med. Chem. 2001, 44, 1794.

15. Collins, R. L. In Experimental Models of Epilepsy; Purpura, P.; Penry, J. K.; Tower, D.; Woodbury, D. M.; Walter, R. Eds; Raven Press: New York, 1972, pp 347-372.

16. De Sarro, G. B.; Croucher, M. J.; Meldrum, B. S. Neuropharmacology 1984, 23, 526.

17. Litchfield, J.; Wilcoxon, F. J. Pharmacol. Exp. Ther. 1949, 96, 99. 